\section{> Gjesteskribent}

\section{Hanne Kristin Rohde}

Politiinspektør/Seksjonssjef

Oslo politidistrikt

Foto Morten Bendiksen

\title{
Ta tiden tilbake
}

\section{Kravet til effektivitet kan ikke med hell etterkommes i enhver sam- menheng. I mellommenneskelige relasjoner er det langsomhet som gjelder.}

I skrivende stund er min mor på snart 81 år hentet av ambulansepersonell og fraktet til Oslo legevakt idet hun ikke kom opp av sengen i dag tidlig pga. voldsom svimmelhet. Hun fikk denne ekstraservicen å bli kjørt dit i ambulanse idet de fremmøtte vurderte at min far på 87 år som er avhengig av krykker, ikke ville være i stand til å hjelpe henne til verken morgentoalett eller påkledning, langt mindre tilå komme seg ut i bil. Nå får hun nødvendig hjelp og det er godt for pårørende. Fullt så tilfredsstillende fungerte det ikke for et par år tilbake da min far, som har diagnosene polynevropati og angina, falt baklengs ned en utvendig murtrapp. Vi fant ham med store hull i hodet, brukne ribben samt uvisst andre eventuelle indre skader. Han ble fraktet i ambulanse til Oslo legevakt, hvor det gikk mange timer til venting mellom akuttbehandling og diverse andre relevante undersøkelser. Det kan forstå seg. Han ble fraktet videre til Ullevål sykehus om kvelden samme dag, med min mor som pårørende i ambulansen. På Ullevål ble det konstatert at de prøver som var nødvendige, ikke kunne gjennomføres før dagen etter, og min omtåkede far ble skrevet ut av vakthavende helsepersonell med beskjed til min mor om å vekke ham hver time hele natten for å sjekke om han responderte adekvat. Det kan legges til at det var helt rolig på avdelingen han ble skrevet ut fra, og nok av sengeplasser.

I forbindelse med påfølgende klage til sykehusledelsen fikk min mor et hyggelig brev med beklagelse av det inntrufne, og at hjemsendelsen den aktuelle kvelden skyldtes en rutinesvikt. Det må selvfølgelig understrekes at vi har hatt flere positive enn negative opplevelser med norsk helsevesen. Ved Seksjon for volds- og seksualforbrytelser ved Oslo politidistrikt har vi regelmessig samarbeid med helsevesenet. Det kan være en siktet drapsmann som trenger medisinsk vurdering eller pårørende til en drept som må ha hjelp. Det kan være voldtektsofre som trenger fysisk og psykisk oppfølging. Eller en varetektsinnsatt som under varetektsperioden blir for syk til å være på celle og må legges inn på sykehus med vakthold. Listen er lang over hjelpetrengende, og informasjonsflyten utfordres tidvis av taushetsplikten, eller tolkningen av denne. Vi kan oppleve at politiets interesser krysses av helsevesenets interesser. Når dette får konsekvenser for enkeltindivid eller for samfunnet generelt understrekes behovet for samspill og åpen dialog for alvor. Vi har god erfaring med samarbeid med helsevesenet fra mitt ståsted i politiet.

Mine erfaringer både som politi og privatperson gir meg refleksjoner til den tid vi lever i. Vi som arbeider innen offentlige etater vet hva det vil si å skjære ned på ressurser. Samtidig forventes vi å levere mer og oppnå best mulig resultater for lavest mulig kostnad. Alt skal effektiviseres, og spørsmålet blir stilt om hvorfor vi leverer mindre når tilskuddene fra staten har økt. Fast-food, e-mail og mengder av teknologiske og andre arbeidsbesparende effektivitetstiltak er en del av vår hverdag - en travel effektivitet som til syvende og sist ofte blir ineffektiv. Mennesker slites ut, kreativitet og utholdenhet svekkes. Hastverk er uforenlig med kvalitet og medmenneskelighet.

Hva trenger vi for å fatte de riktige beslutningene i den virkelighet vi står i?

For å levere må organisasjonens medarbeidere blomstre. Og da vil jeg minne om at det er noe som aldri kan effektiviseres, og det er de mellommenneskelige relasjonene. En tilsynelatende selvfølgelighet som ser ut til å gå litt i glemmeboken mens vi løper i korridorene, når tiden uteblir og vi mister hverandre på veien. Vi må bruke tid på hverandre. Jeg oppfordrer til langsomhet i mellommenneskelige relasjoner, både privat og på arbeidsplassen. Pasienten er mer enn én av mange. Den berørte i en straffesak er mer enn én av mange. Vi må ta tiden tilbake. Vi må sette mennesket foran tingene.

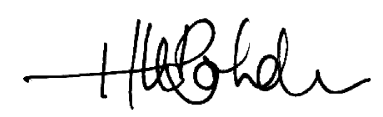

